\title{
Immuno-hematological Profile Trends of HIV/AIDs Patients on HAART in the South West Region of Cameroon: Retrospective Medical Report Review for Possible Stratified follow-up Pattern in Low Income Settings
}

\author{
Simon Eyongabane Ako ${ }^{1,2, *}$, Longdoh Anna Njunda ${ }^{1}$, Eric Achidi Akum ${ }^{3}$, Pokam Thumamo Benjamin ${ }^{1,4}$, \\ Julius Clement Assob ${ }^{1}$, Jude Eteneneng Enoh ${ }^{1,5}$, Wabo Bernard ${ }^{1}$, Njiomegnie Gaitan Fabrice ${ }^{1}$ \\ ${ }^{1}$ Department of Medical Laboratory Sciences, Faculty of Health Science .University of Buea, P.O.Box 63, Buea, Cameroon \\ ${ }^{2}$ Biaka University Institute of Buea, School of Health Science \\ ${ }^{3}$ Faculty of Science, University of Buea, P.O. Box 63, Buea, Cameroon \\ ${ }^{4}$ Noguchi Memorial Institute for Medical Research, University of Ghana, Legon- Accra, Ghana \\ ${ }^{5}$ Laboratory of Endocrinology and Radio-element (LER), Medical Research Center (CRM), Institute of Medical Research and \\ Medicinal Plants studies (IMPM) \\ *Corresponding author: youngabane@yahoo.com
}

Abstract Background: If found with people infected with human immunodeficiency virus (HIV), Immunohematological abnormalities can increase the risk of disease progression and death. Inorder to understand the pattern of the immune and hematology cells during Antiretroviral (ARV) therapy, we reviewed and analyse the immunehematological profiles of HIV patients to determine the possible parameters and patterns that could be used to follow up patients in low income setting where the access of viral load testing is still not affordable. Methodology: A descriptive hospital based cross-sectional study of 285 HIV-1/AIDS adult patients on highly active antiretroviral therapy (HAART) was carried out from January to May, 2015. Review of participants records was also done to obtain baseline and other progressive data. A total of Four groups were created based on the patients duration on HAART. The composition was as follows: Group I (6months - 1year), group II (>1year - 3years), group III (>3years - 5years) and group IV ( $>$ 5years). After the achieve data was obtain, venous blood was collected, and the number of CD4+ and CD8+ T cells count measured using a flow cytometer. The level of Hemoglobin, number of Platelets, total and differential White Blood Cells were enumerated with automated hematology analyzer. Analyses was carried out to determine changes in various parameters with respect to established baseline values. Results : The pattern for CD4+ T cell at stratified baseline count between $<99-499$ cells/ $\mu 1$, showed a significant progressive increase from group I to group IV; while CD4+ T cell at stratified baseline count $>500 \mathrm{cells} / \mu \mathrm{l}$ had a reversing turn, decreasing gradually among groups II, III and IV, and drastically in group I. The pattern for CD8+ T cell at stratified baseline count between $<500$ - 999 cells/ $\mu$ l, increased progressively from group I to IV, remaining at the normal range; while at stratified baseline count between $>1000$ cells $/ \mu$, the pattern decreased gradually from group I to IV, with group II showing a significant decrease. Also hemoglobin baseline level between $<7-12 \mathrm{~g} / \mathrm{dl}$, showed a pattern with significant increase among all groups to normal hemoglobin level. With platelets baseline between $<150$ $399 \mathrm{cells} / \mu \mathrm{l}$, the pattern of all the groups increased and stayed within normal range, but platelets baseline at $>400 \mathrm{cells} / \mu \mathrm{l}$ showed a reversing turn, with significant decreases to normal level. Furthermore eosinophil baseline at $<3 \%$, showed a pattern of constant increase to abnormal levels in groups I,II and III; while group IV had a reversing decreasing pattern to normal levels meanwhile eosinophil baseline at $>3 \%$, had a significant decreasing pattern from group I to IV. Leukocytes stratified baseline count at $<4000 \mathrm{cells} / \mu \mathrm{l}$ had an irregular increasing pattern from group II to IV, then group I and finally group III, while leukocytes stratified baseline count at $>4000 \mathrm{cells} / \mu \mathrm{l}$ had a similar pattern but reversed in group III and group I. in addition neutrophil at baseline count $<40 \%$ had a significant progressive increasing pattern from group I to IV, but neutrophil baseline count $>40 \%$ had an irregular increasing pattern from group II to group III, followed by group I and finally group IV. Conclusion: Group I profile can be used to detect early complications in patients using CD4+ T cell, hemoglobin, platelets, WBC, and neutrophils counts; while CD4+ T cell, hemoglobin, platelets, WBC, neutrophils count and CD8+ T cell baseline of $>1000$ cells $/ \mu \mathrm{L}$ count can be used to monitor the patients' successful treatment outcome on HAART in group II,III and IV. Starting ARV treatment with a CD4+ T cell of $>500$ cells might not be advisable, we equally observed that eosinophils variation is associated with treatment duration. Further studies with larger sample sizes are recommended to make affirmative conclusions. 
Keywords: HIV, AIDs, HAART, immunohematology parameters, Treatment follow-up, South West,

Cite This Article: Simon Eyongabane Ako, Longdoh Anna Njunda, Eric Achidi Akum, Pokam Thumamo Benjamin, Julius Clement Assob, Jude Eteneneng Enoh, Wabo Bernard, and Njiomegnie Gaitan Fabrice, "Immuno-hematological Profile Trends of HIV/AIDs Patients on HAART in the South West Region of Cameroon: Retrospective Medical Report Review for Possible Stratified Follow-up Pattern in Low Income Settings." American Journal of Microbiological Research, vol. 6, no. 2 (2018): 47-56. doi: 10.12691/ajmr-6-2-3.

\section{Introduction}

Hematological parameters are important monitoring tools for assessing treatment and prognosis in Human Immunodeficiency Virus (HIV) infected patients [1,2,3]. Immunologic parameters such as CD4+T cell counts have been viewed as the best predictor of the risk of developing AIDS-related complications, and as such, they have been used to monitor disease progression; determine prognosis; select patients for therapeutic trials and monitor therapy. However, CD4+ T cell counts alone seems to be an inadequate immunological parameter to measure prognosis and antiretroviral therapy [4]. Other factors like duration on Antiretroviral (ARV) and CD8 $+\mathrm{T}$ cell count might be required in low income settings for better management due to absence of viral load testing. Immuno-hematological profiles used in monitoring HIV/AIDS patients involve total and differential WBC (FULL), hemoglobin concentration and platelet count [5]. Besides CD4+ $\mathrm{T}$ cell and $\mathrm{CD} 8+$ $\mathrm{T}$ cell count, decrease in $\mathrm{CD} 4+\mathrm{T}$ lymphocytes count, hemoglobin concentration, platelet count, WBC, neutrophil count; and an increased in CD8 $+\mathrm{T}$ lymphocytes and eosinophil count are characteristics of HIV-1 patients failed response to ARV therapy or those not yet on ART [6]. An effective application of the immune-hematological profiles involves the use of all the available results from the immune and hematologic parameters to make decisions on the next step or approach in the patient's management. Global update studies have shown that effective application of immune-hematological profiles can lead to an improved survival of the HIV/AIDS patient [7]. With the variety in HIV strains among different regions in the world, it is possible that the ART response profiles might not be the same [8]. The duration on HAART has been shown to have an impact in the understanding of the kinetics of viremia and CD4 counts [9].Using immune and hematology data from other regions and countries as a control tool in both short or long term monitoring of HIV patients in other local setting might be ineffective. There are challenges which could compromise the goals of ART, including failed/incomplete treatment responses [10], drug interaction and toxicity [11], drug resistance [12,13], lost to follow up and early mortality [14].Though some studies on immunologic parameters of HIV-1 patients on HAART in Cameroon $[15,16]$, have been carried out, comparative studies on other immunohematological parameters at specific time duration of treatment of HIV positive patients in the country are scarce. Moreover, other immunohematological parameters apart from CD4 and hemoglobin concentration have not been documented in the South West Region of the country that might be useful for follow up to determine the success at different durations on treatment of HIV patients. Understanding the changes in the immune-hematological profile trends during treatment can help to prevent most of the adverse effects on HIV patients in our community. This study, therefore, assesses the immunohematological parameters of HIV positive patients on HAART at different treatment duration with the hope to improve the ARV treatment outcome of HIV/AIDs patients in the South West Region of Cameroon.

\section{Material and Methods}

\subsection{Research Design}

A descriptive hospital based cross-sectional study of 285 HIV-1/AIDS adult patients on highly active antiretroviral therapy (HAART) was carried out from January to May, 2015. Review of participants records was also done to obtain baseline and other progressive data. A total of Four groups were created based on the patients duration on HAART. The composition was as follows: Group I (6months - 1year), group II (>1year - 3years), group III ( $>3$ years - 5years) and group IV ( $>5$ years). After the achieve data was obtain, venous blood was collected, and the number of CD4+ and CD8+ T cells count measured using a flow cytometer. The level of Hemoglobin, number of Platelets, total and differential White Blood Cells were enumerated with automated hematology analyzer. Analyses was carried out to determine changes in various parameters with respect to established baseline values

\subsection{Study Area}

The data for the study was carried out from the Buea Regional Hospital, Limbe Regional Hospital, Kumba District Hospital, Mamfe District Hospital and Muyuka District Hospital, all these institutions are authorised HIV treatment centers located in the South West region of Cameroon.

\subsection{Study Population}

A total of two hundred and eighty five (285) patients with HIV receiving HAART from the aforementioned treatment centres were chosen for this study. Demographic data were obtained through questionnaires, while infections and treatment histories were obtained from review of medical records. Participants' adherence history on HAART was also obtained through officials in charge of administering treatments, and from participants' medical records.

Participants were divided into four groups with respect to duration on HAART: where group I (6months - 1year), group II (>1year - 3years), group III ( $>3$ years - 5years) and group IV ( $>5$ years). 


\subsection{Ethical Consideration}

An authorization to carry out this study was obtained from the Faculty of Health Science Institutional Review Committee. Written and signed informed consent were gotten from all the participants.

\subsection{Data Collection and Processing}

Patients hospital records were review and venous blood sample was collected and the level of hemoglobin,the number of Platelets, the total and differential White Blood Cells were analysed using automated Hematology Analyzer (Hematology analyzer Sysmex KX-21, corporation Kobe, Japan). CD4+ and CD8+ T lymphocytes counts were analysed using standardised Flow cytometric cyflow machine (BD Biosciences FACSCount, New Jersey, USA). Data were collected based on the treatment duration and the baseline parameters were stratified on the basis of their pre-therapeutic measurement.

\subsection{Data Analysis}

The data were edited, checked for completeness and processed using Excel 2013, and exported to the Statistical Package for Social Sciences (SPSS ) version 20 (SPSS Inc., Chicago. IL. USA) for Windows. The student's t- test, Wilcoxon test for pairwise data, and general linear models were used to assess differences in group means (baseline and present means of each stratified hematological Parameters (hemoglobin, platelet, WBC, neutrophil, eosinophil) and immunological parameters (CD4+ and $\mathrm{CD} 8+\mathrm{T}$ cell). The $\mathrm{P}$ value $<0.05$ was considered to be statistically significant.

\section{Results}

\subsection{Baseline Characteristics of the Studied Participants}

Of the $285 \mathrm{HIV}$ infected patients on treatment selected for the study, 71 were in group I (6 months to 1year), 72 in group II (1 year to 3 years), 71 in group III (3 years to 5 years) and 71 in group IV (greater than 5 years). Also about $216(75.8 \%)$ were females and $69(24.2 \%)$ were males. The overall mean age was $41 \pm 11$ years (Table 1 ), within the range of 20 - 75 years of age. A large majority of the patients, $(35.4 \%)$ were within 36 - 45 years of age (Table 1). Five treatment regimens were frequently used.172 $(60.4 \%)$ were on regimen D; $51(17.9 \%)$,on regimen $\mathrm{A} ; 48(17.2 \%)$ on regimen $\mathrm{C}$; and lastly, 5 (1.8\%) in regimen $2 \mathrm{C}$. The mean baseline $\mathrm{CD} 4 \mathrm{~T}$-cell count for most of the patients indicated that they were initiated at WHO clinical stage II, meanwhile the mean baseline for hemoglobin concentration of the majority of the patients was less than $11 \mathrm{~g} / \mathrm{dl}$. The mean baseline for parameters including CD8, platelet, WBC, neutrophil and eosinophil were within normal levels (Table 1).

Table 1. Baseline demographic characteristics of the study participants

\begin{tabular}{|c|c|c|c|c|c|}
\hline \multirow[b]{2}{*}{ VARIABLES } & \multirow[b]{2}{*}{$\begin{array}{l}\text { ARV patients } \\
\quad(n=285)\end{array}$} & \multicolumn{4}{|c|}{ DURATION ON HAART } \\
\hline & & $\begin{array}{l}6 \text { months - 1year } \\
(\mathrm{n}=71)\end{array}$ & $\begin{array}{c}>1 \text { year }-3 \text { years } \\
(n=72)\end{array}$ & $\begin{array}{c}>3 \text { years }-5 \\
\text { years } \\
(n=71)\end{array}$ & $\begin{array}{c}>5 \text { years } \\
(n=71)\end{array}$ \\
\hline \multicolumn{6}{|l|}{ AGE } \\
\hline $20-35$ & $93(32.6 \%)$ & $36(50.7 \%)$ & $27(37.5 \%)$ & $19(26.8 \%)$ & $11(15.5 \%)$ \\
\hline $36-45$ & $106(37.2 \%)$ & $25(35.2 \%)$ & $31(43.1 \%)$ & $26(36.6 \%)$ & $24(33.8 \%)$ \\
\hline$>45$ & $86(30.2 \%)$ & $10(14.1 \%)$ & $14(19.4 \%)$ & $26(36.6 \%)$ & $36(50.7 \%)$ \\
\hline \multicolumn{6}{|l|}{ SEX } \\
\hline MALE & $69(24.2 \%)$ & $22(31.0 \%)$ & $17(23.6 \%)$ & $13(18.3 \%)$ & $17(23.9 \%)$ \\
\hline FEMALE & $216(75.8 \%)$ & $49(69.0 \%)$ & $55(76.4 \%)$ & $58(81.7 \%)$ & $54(76.1 \%)$ \\
\hline \multicolumn{6}{|l|}{ REGIMEN } \\
\hline A (AZT/3TC/NVP) & $51(17.9 \%)$ & $6(8.5 \%)$ & $8(11.1 \%)$ & $16(22.5 \%)$ & $21(29.6 \%)$ \\
\hline B (AZT/3TC+EFV) & $8(2.8 \%)$ & $0(0 \%)$ & $4(5.6 \%)$ & $1(1.4 \%)$ & $3(4.2 \%)$ \\
\hline C (TDF/3TC+NVP) & $48(17.2 \%)$ & $16(22.5 \%)$ & $15(20.8 \%)$ & $9(12.7 \%)$ & $9(12.7 \%)$ \\
\hline D (TDF/3TC/EFV) & $172(60.4 \%)$ & $47(66.2 \%)$ & $45(62.5 \%)$ & $44(62.0 \%)$ & $36(50.7 \%)$ \\
\hline 2C(TDF/3TC+LPV/r) & $5(1.8 \%)$ & $2(2.8 \%)$ & $0(0 \%)$ & $1(1.4 \%)$ & $2(2.8 \%)$ \\
\hline \multicolumn{6}{|l|}{ MEAN } \\
\hline $\mathrm{CD4}^{+}$T CELL $($cell $/ \mu \mathrm{L})$ & & 233.77 & 236.76 & 237.79 & 233.83 \\
\hline $\mathrm{CD8}^{+}$T CELL $($cell $/ \mu \mathrm{L})$ & & 1086.32 & 1184.56 & 1092.49 & 1123.58 \\
\hline HEMOGLIBIN (g/dL) & & 10.18 & 10.03 & 10.47 & 10.71 \\
\hline PLATELET (cell/ $\mu \mathrm{L})$ & & 221.93 & 239.39 & 236.06 & 261.94 \\
\hline WBC (cell/ $/ \mu \mathrm{L})$ & & 4307 & 4664 & 4628 & 4617 \\
\hline NEUTROPHIL (\%) & & 44.41 & 46.67 & 47.13 & 45.58 \\
\hline EOSINOPHIL (\%) & & 2.38 & 2.14 & 3.30 & 3.04 \\
\hline
\end{tabular}




\subsection{Immuno-hematological Profile Trends of HIV/AIDS Patients on Highly Active Anti-Retroviral Therapy (HAART)}

\subsubsection{CD4+ T CELL}

The CD4+ T cell increased significantly among groups I, II, III and IV in comparison to stratified baseline between $<99$ - 499cells $/ \mu$ l. Conversely, at baseline $>500$ cells $/ \mu \mathrm{l}$, CD4+ T cells significantly decreased among all groups (Figure 1). Following baseline stratified count between $<99$ - 499 cells/ $\mu$, groups I, II and IV had a constantly increasing pattern that varies from 92.3 to 611 cells $/ \mu$ l (group I), 217.1 to 797.2 cells/ $\mu$ l (group II), and 407.3 to 1003.3 cells/ $\mu$ (group IV), while group III had an irregular increasing pattern (Figure 1). Meanwhile, following baseline stratified count at $>500$ cells $/ \mu 1$, group I, II, III and IV significantly decreased to 187.5 cells $/ \mu 1$, 405 cells $/ \mu \mathrm{l}, 368$ cells $/ \mu \mathrm{l}$ and 389 cells $/ \mu 1$ respectively (Figure 1).

\subsubsection{CD8+ T CELLS}

The CD8+ $\mathrm{T}$ cells variation with respect to stratified baseline between $<500-999$ cells/ $\mu$ l, had no significant increase among all the different groups. Meanwhile, CD8+ T cells counts decreased significantly among groups II, III and IV when compared to baseline at $>1000$ cells $/ \mu$ l (Figure 2). Following CD8+ T cells baseline between
$<500$ - 999 cells $/ \mu 1$, all the groups had an increase and stayed at the normal level, with group I pattern varying between 500 to 899.7 cells/ $\mu$, group II (535.8 to 877.9 cells/ $\mu \mathrm{l})$, group III (799 to 876.7 cells/ $\mu \mathrm{l})$, and group IV (748 to 897.9 cells $/ \mu \mathrm{l}$ ). A reversing pattern was observed with CD8 $+\mathrm{T}$ cells baseline at $>1000$ cells $/ \mu \mathrm{l}$, starting from group I (1304.1 cells/ $\mu \mathrm{l})$ to group II $(1241.1 \mathrm{cells} / \mu \mathrm{l})$, followed by group III $(1085.5$ cells $/ \mu \mathrm{l})$ and down to group IV (1056.2 cells/ $\mu$ l) (Figure 2).

\subsubsection{Hemoglobin Concentration}

There were significant differences in the hemoglobin concentration among group I, II, III and IV when compared to their stratified baseline. With stratified baseline hemoglobin concentration at $<7 \mathrm{~g} / \mathrm{dl}$, groups II and III significantly increased to 9.1 and 9.7 respectively. Meanwhile, compared to groups I, II, III and IV, hemoglobin baseline between $7-12 \mathrm{~g} / \mathrm{dl}$ increased significantly, showing a constantly increasing pattern (Figure 3).

\subsubsection{Platelets}

The platelet count increased significantly among groups I, II and III when compared to baseline at $<150$ cells $/ \mu$ l. On the contrary, platelet count decreased significantly among groups I, II, and III when compared to baseline at $>400$ cells $/ \mu$ l (Figure 4). There was no significant change in the levels of platelet in comparison to baseline between $>150$ - 399 cells/ $\mu$ l.

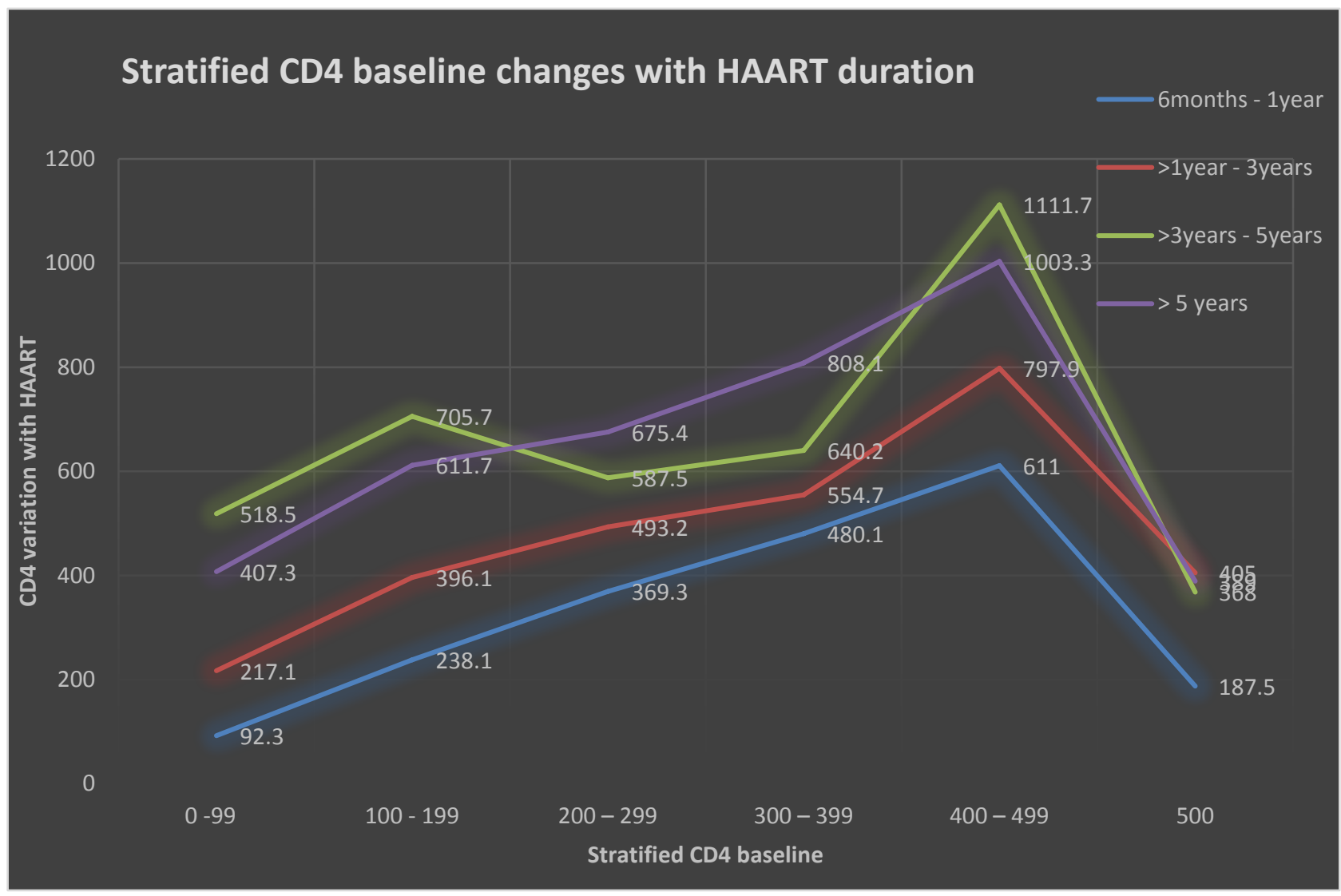

LEGEND

Red $=$ group I (6months -1 year on HAART $)$

Gray $=$ group II $(>1$ year -3 years on HAART $)$

Yellow $=$ group III $(>3$ years -5 years on HAART $)$

Blue $=$ group IV $(>5$ years on HAART $)$

Figure 1. Stratified baseline CD4+ T cells variation with HAART duration 


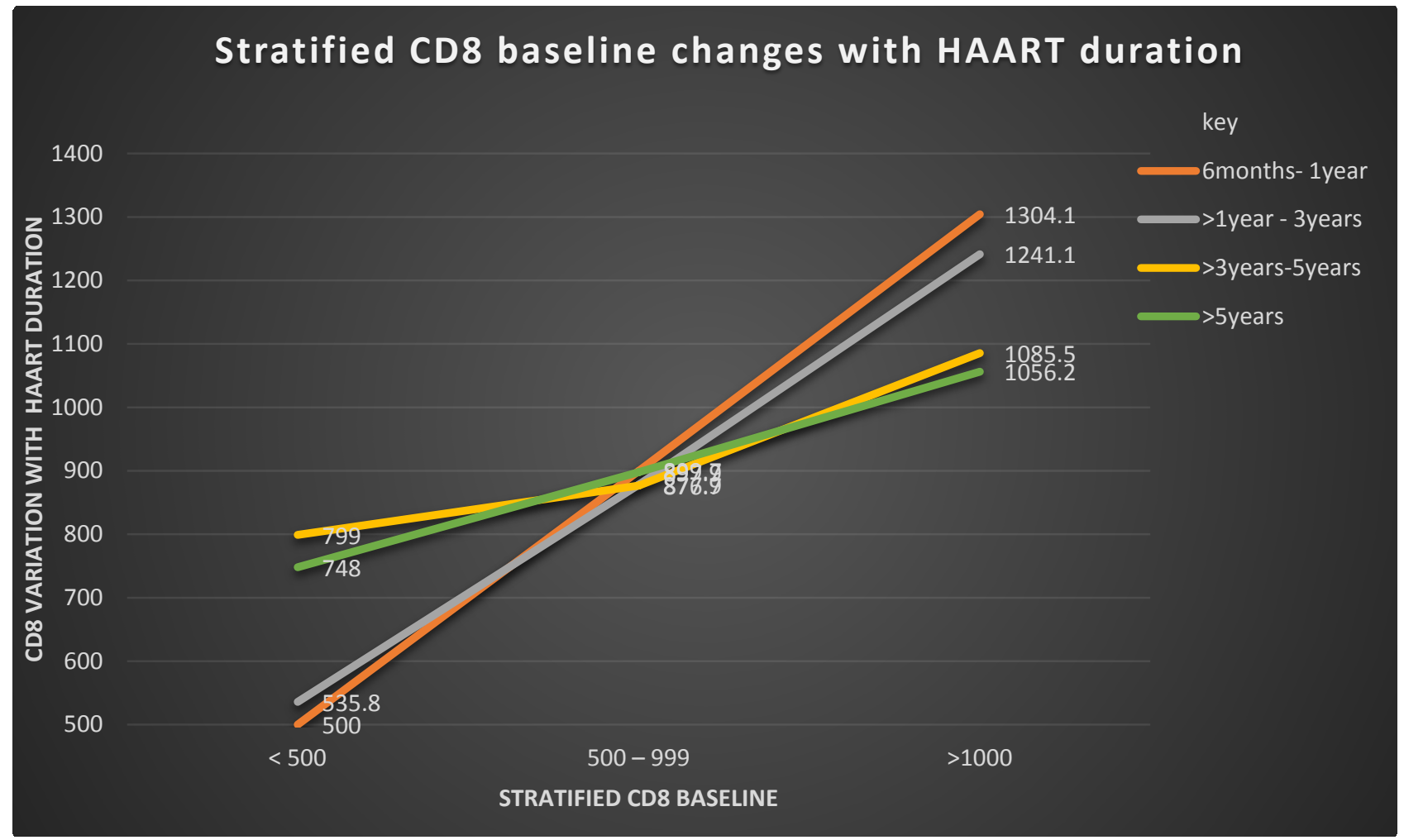

LEGEND

Red $=$ group I (6months -1 year on HAART)

Gray $=$ group II $(>1$ year -3 years on HAART $)$

Yellow $=$ group III $(>3$ years -5 years on HAART $)$

Blue $=$ group IV $(>5$ years on HAART $)$

Figure 2. Stratified baseline CD8+ T cells variation with HAART duration

\section{Stratified hemoglobin baseline changes with HAART duration}
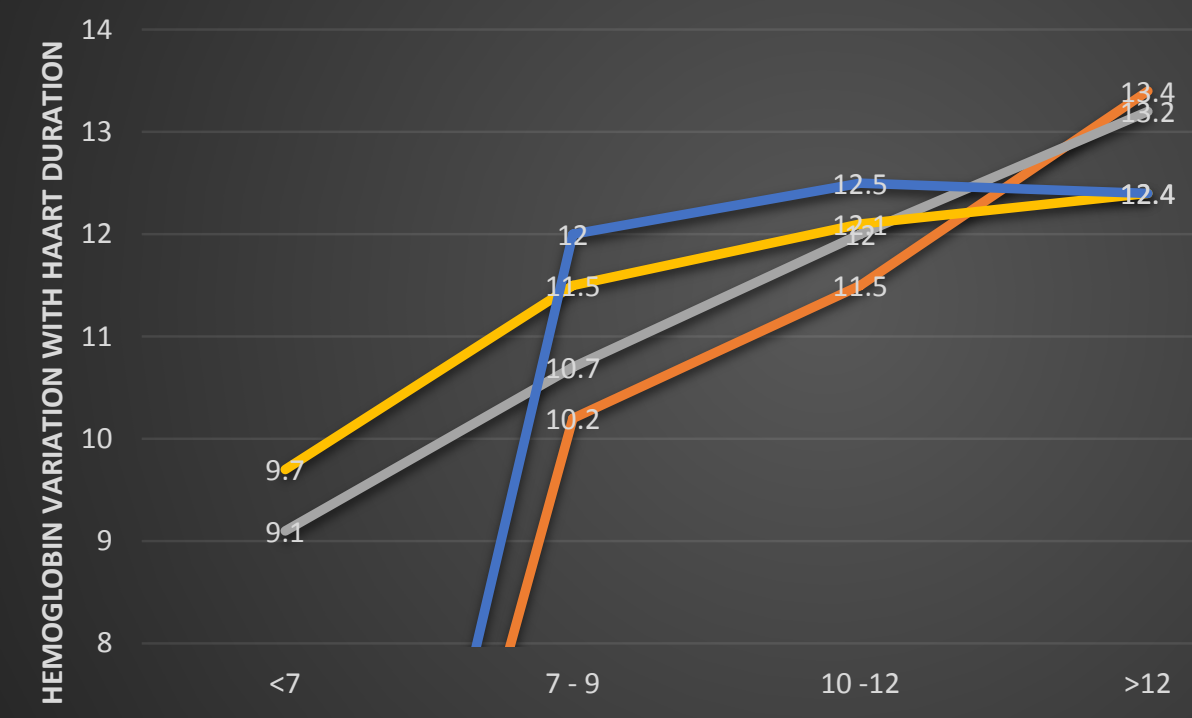

LEGEND

Red $=$ group I $(6$ months -1 year on HAART $)$

Gray $=$ group II $(>1$ year -3 years on HAART $)$

Yellow $=$ group III $(>3$ years -5 years on HAART $)$

Blue $=$ group IV $(>5$ years on HAART $)$ 


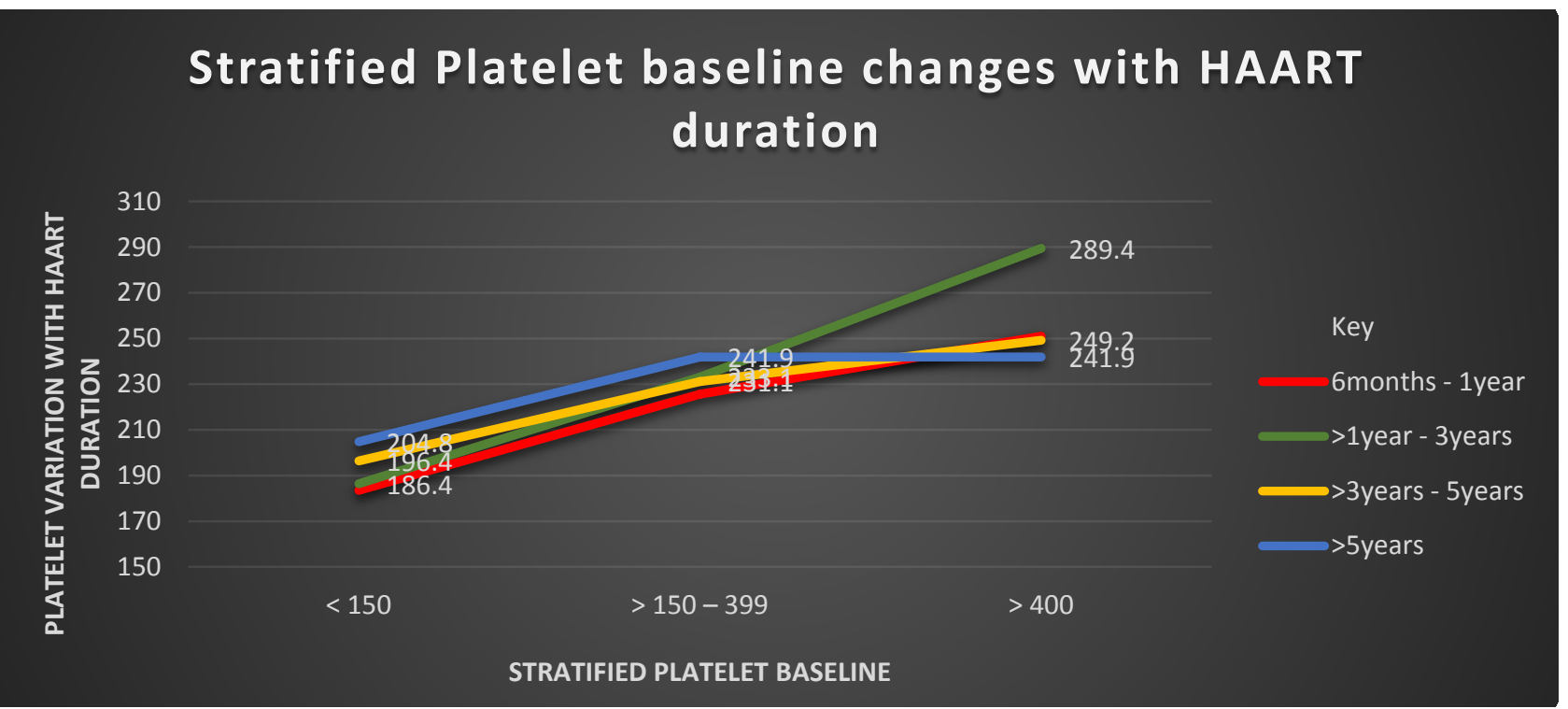

LEGEND

Red = group I (6months -1 year on HAART)

Gray $=$ group II $(>1$ year -3 years on HAART $)$

Yellow $=$ group III $(>3$ years -5 years on HAART $)$

Blue $=$ group IV $(>5$ years on HAART $)$

Figure 4. stratified platelets baseline count variation with HAART duration

\subsubsection{White Blood Cells}

The total White cell count from baseline $<4000$ cells $/ \mu \mathrm{l}$ increased significantly among all groups in an irregular pattern (Figure 5), with the highest among group III $(5264 \mathrm{cells} / \mu \mathrm{l})$, followed by group I $(5104$ cells $/ \mu \mathrm{l})$, group IV (4926 cells $/ \mu \mathrm{l})$ and finally group II $(4800$ cells $/ \mu \mathrm{l})$ (Figure 5). There were no significant changes between the baseline at $>4000$ cells $/ \mu$ l when compare to all the various groups.

\subsubsection{Eosinophil}

Following baseline stratified eosinophil count at $<3 \%$, groups I, II and III significantly increased to $3.1 \%, 3.3 \%$ and $3.1 \%$ respectively; conversely to group IV that significantly decreased to $2.7 \%$ (Figure 6). At eosinophil baseline count $>3 \%$, only groups III and IV significantly decreased to $3.2 \%$ and $2.9 \%$ respectively; meanwhile, groups I and II had no significant changes.

\subsubsection{Neutrophil}

Neutrophil increased significantly among groups I, II, III and IV in comparison to stratified baseline at $<40 \%$. Conversely, at baseline $>40 \%$, only groups I and IV had significant differences (Figure 7).

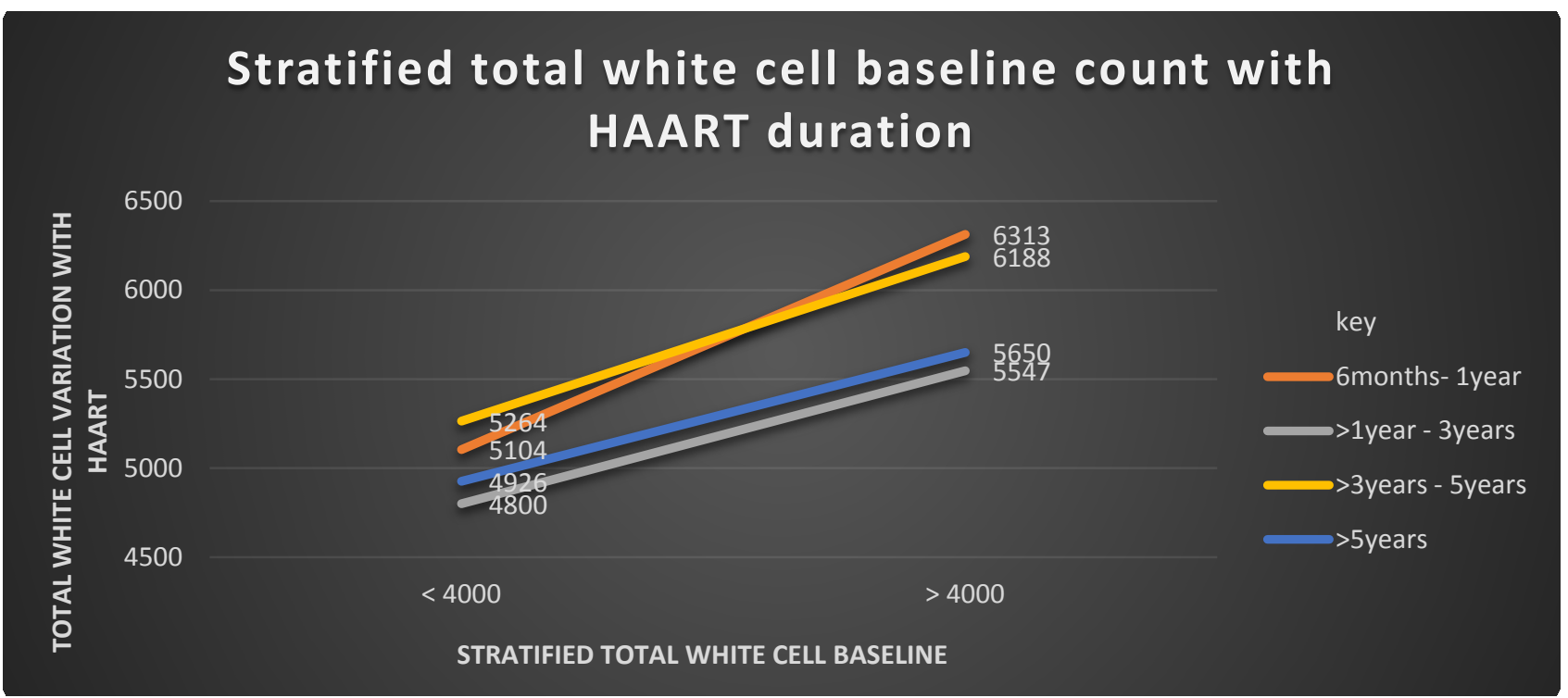

\section{LEGEND}

Red $=$ group I (6months -1 year on HAART)

Gray $=$ group II $(>1$ year -3 years on HAART $)$

Yellow $=$ group III $(>3$ years -5 years on HAART $)$

Blue $=$ group IV $(>5$ years on HAART $)$ 


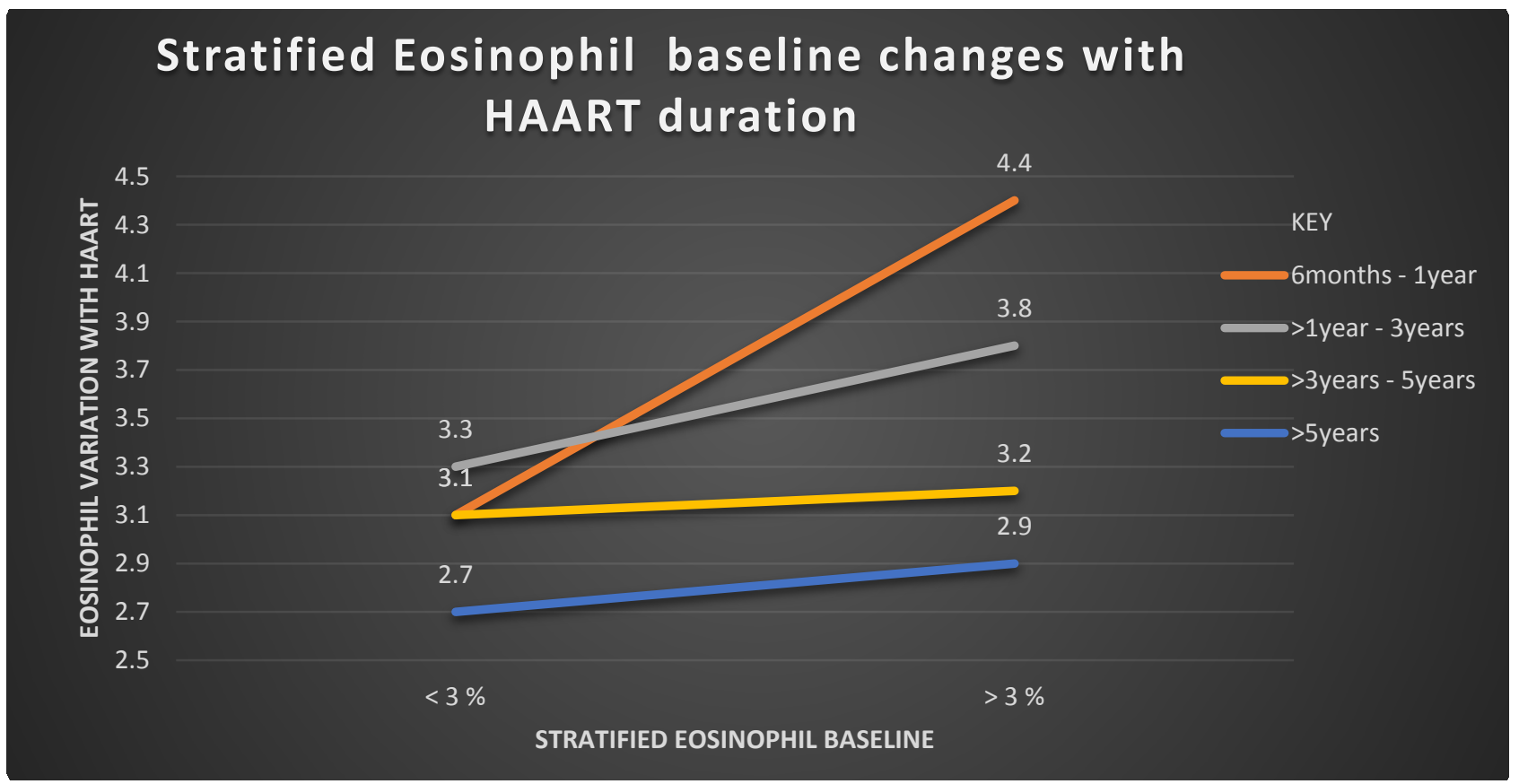

LEGEND

Red $=$ group I $(6$ months -1 year on HAART $)$

Gray $=$ group II $(>1$ year -3 years on HAART $)$

Yellow $=$ group III $(>3$ years -5 years on HAART $)$

Blue $=$ group IV $(>5$ years on HAART $)$

Figure 6. Stratified baseline eosinophil variation with HAART duration

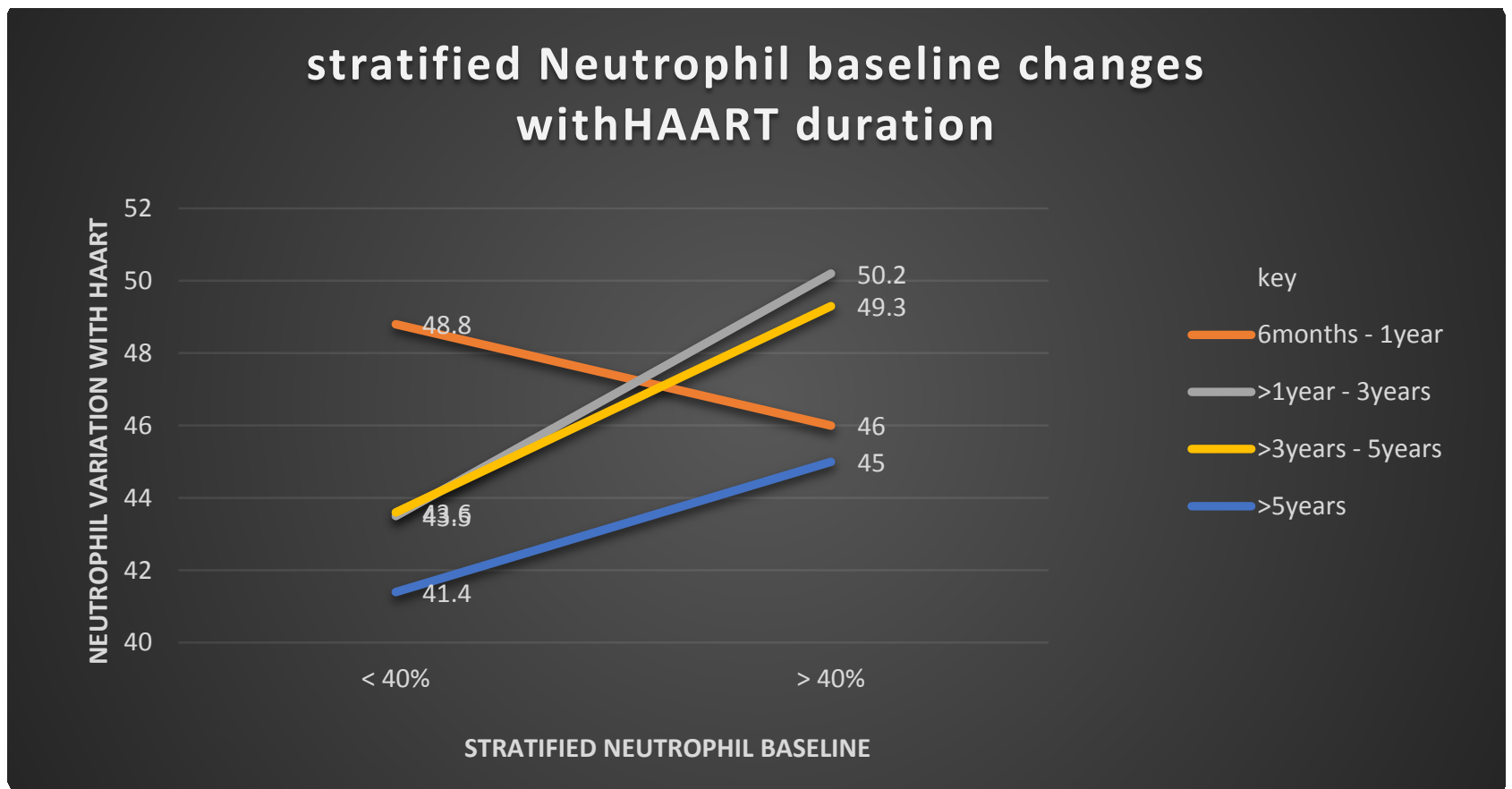

LEGEND

Red $=$ group I (6months -1 year on HAART)

Gray $=$ group II $(>1$ year -3 years on HAART $)$

Yellow $=$ group III $(>3$ years -5 years on HAART $)$

Blue $=$ group IV $(>5$ years on HAART $)$

Figure 7. Stratified baseline neutrophil variation with HAART duration

\section{Discussion}

This study evaluated the changes from stratified baseline values and duration on HAART to illustrate possibilities of predicting early complications and patients' success on treatment.
Among the tested parameters, the CD4+ T cells trend showed a sharp significant increase among groups I, II, III and IV in comparison to stratified baseline between $<99$ 499 cells $/ \mu 1$. This is in line with Moore and Keruly [17] who show a slope of plotted CD4+ Tcell count values for each of the baseline CD4+ Tcell count strata after the 
initiation of HAART, increasing progressively before reaching a plateau by the fourth year of sustained viral suppression in all CD4+ $\mathrm{T}$ cell count strata. The findings of our study are in contrast to Michael et al., [18] who demonstrate that in a 36 month of follow-up study, levels of both total and naive CD4+ cells increased only in the $18^{\text {th }}$ month and stabilised thereafter at an abnormal level. Studies have equally revealed that the recovery of CD4+ T cells occurs in two phases; the rapid recovery phase that occurs during the first two months after initiation of HAART due to the release of the sequestered cells in the body tissue; and the second phase which is the slow recovery phase that occurs from the third month onwards due to regeneration of new cells from bone marrow and the reduction of programmed cell death $[19,20]$.

Conversely, at baseline $>500$ cells $/ \mu 1, \mathrm{CD} 4+\mathrm{T}$ cells trend significantly decreased among all groups. Similar findings were reported in a Multicentre AIDS Cohort Study and the Women's Interagency HIV Study carried out by Chu et al., [9] that indicated that, at a pre-HAART CD4 cell count greater than 500 cells/mm3, CD4+ T cell significantly declines after change points. Thus, it did not have a sustained response to long-term HAART usage .Further research into the causes of such reversing trends may be warranted, and there is the need to search for additional therapies or different combinations of regimens that will further boost immune reconstitution.

The CD8+Tcell count trend demonstrated a decreasing trend among groups II, III and IV when compared to baseline at $>1000$ cells $/ \mu \mathrm{l}$. The findings were similar to other studies that reported a significant decline in mean CD8 cell counts among patients who had been on HAART for at least 12 months $[21,22]$. CD8+ T-lymphocytosis is another major cellular element of interest in the HIV disease that is involved in two roles of immune defense: suppressing the cell mediated response to limit damage to host tissue; and attacking cells infected with virus directly [23]. Researchers have found out that viral load is better controlled in people whose HIV-specific CD8 Tcells mature fully into 'effector memory' T-cells [24,25].

With the hemoglobin parameter, the hemoglobin concentration showed a sharp increasing trend from stratified baseline between $<7-12 \mathrm{~g} / \mathrm{dl}$ among groups I and II, followed by a plateau in groups III and IV. These findings are in line with those of other studies that reported significant increase in hemoglobin level after initiation of HAART, with a statistical association between the level of hemoglobin and the duration of use of HAART [26,27]. The positive effect of HAART is probably due to the reduction in viral load, decreased destruction of mature hematopoietic cells of multiple lineages and an improvement in the blunted erythropoietin response [28].

Among patients receiving HAART with $95 \%$ adherence rate, an increase in platelet count was recorded and maintained from baseline strata between $<150$ - 399 cells/ $\mu$ l in groups I, II and III. Similar findings were recorded in Landro et al., [29]. However, patients with a baseline of $>400$ cells $/ \mu$ l decreased significantly to normal levels among all groups. Also platelets has proven to be involved in regulating HIV infection through the release of mediators such as chemokines (RANTES/CCL5 and NAP-2/CXCL7) [30,31]. RANTES have equally shown some beneficial effects in HIV infected patients by inhibiting HIV entry into cells and by binding to the HIV coreceptor CCR5 [32].

Furthermore the white blood cell count showed sharp increasing trends from stratified baseline between $<4000$ and $>4000$ cells $/ \mu$ among all groups. Our findings extend previous reports, that revealed that there is a significant increase in the median absolute total leukocytes when compared to baseline after HAART initiation [33]. However our findings are contrary to those of a study that reported a decrease in WBC with duration of ARV therapy [34]. The white blood cell profile showed that the white cell count improved with HAART irrespective of the baseline in all groups and remained in the normal range.

The data on eosinophil count shows that at baseline $<$ $3 \%$, groups I, II and III instead increased to abnormal high levels (eosinophilia), while only group IV remains at the normal level. Conversely, at eosinophil baseline $>3 \%$, only groups III and IV trends dropped to normal ranges; meanwhile, groups I and II stayed at the abnormal high level. Studies have shown that eosinophilia is encountered in as high as $28 \%$ of patients with HIV infection [35]. Other studies have associated eosinophilia with low CD4 counts [36,37], but studies associating eosinophilia with duration on HAART were limited.

After the initiation of HAART, the neutrophil had a constantly increasing trend among all groups in comparison to stratified baseline at $<40 \%$. Meanwhile, at baseline $>40 \%$, only groups I and IV had significant differences. These findings are in line with those of a study that observed a significant increase in the median neutrophil count in comparison to baseline after HAART initiation [33]. Researchers have shown that the functional improvement of components of innate antimicrobial immunity, such as neutrophils may contribute to improved cell-mediated immune responses against opportunistic infections in HAART-treated patients [33].

\section{Conclusion}

Different immunohematological parameters can be implemented to follow-up patients on HAART if the baseline data and duration on HAART is known. From baseline between $<99-499$ cells/ $\mu 1$, CD4 + T cells profiles can be used to monitor the patients' success on HAART. High baseline CD4+T cell counts at $>500$ cells/ $\mu 1$ with the present HAART regimens are significant risk factors for developing immunological failure. Also CD8+Tcell count profile can be specifically used to monitor treatment only after one year on HAART with patients who were initiated with a baseline CD8+Tcell count at $>1000$ cells $/ \mu$ l. As observed in our study hemoglobin concentration improved with HAART irrespective of the baseline in all groups and remained stable among groups III and IV. Furthermore the platelet profile shows that with the present HAART regimens, not only platelets improvement was noted, but also the ability of bringing abnormal high platelet counts to normal levels was possible. Thus, white cell count can be used to predict treatment outcomes among patients. Our study had equally established that in the eosinophil profile at high baseline eosinophil count $>3 \%$, groups III 
and IV trend could be used to evaluate treatment outcome, meanwhile, at baseline $<3 \%$, only group IV trend could be useful in predicting treatment outcome.

\author{
Abbreviations \\ ARV: Anti-Retroviral Therapy, \\ HAART: Highly Active Antiretroviral Therapy, \\ UPEC: Unit In charge of People Living with HIV/AIDS, \\ AZT: Zidovudine, \\ 3TC: Stavudine, \\ NVP: Nevirapine, \\ EFV: Efavirenz, \\ TDF: Tenofovir Disoproxil fumarate, \\ LPV/r: Liponavir/Ritonavir
}

\section{Ethical Approval}

This study was approved by the Faculty of Health Sciences Institutional Review Board, University of Buea, Cameroon.

\section{Availability of Data and Materials}

At the University of Buea, Cameroon main Library

\section{Competing Interests}

The authors declare that they have no competing interests

\section{Acknowledgements}

The authors would like to thank the directors, laboratory and UPEC staff of the Buea Regional Hospital, Limbe Regional Hospital, Mamfe District Hospital, Kumba District Hospital and Muyuka District Hospital, for their permission and help in the collection, processing and analysis the laboratory test. Also we thank all our participants for their cooperation and the delegate of public Health in the South west Region of Cameroon for administrative authorization.

\section{References}

[1] Tripathathi AK., Pramila K., Misra R., Kumar A., Neetu G. Study of bone marrow abnormalities in patients with HIV Disease. JAPI 2005; 53: 105-110.

[2] Bain BJ. The haematological features of HIV infection. Br Journal Haematology, 1997; 99: 1-8.

[3] Coyle TE. Management of the HIV infected patients. Part II. Med Clin North America 1997; 81: 449-470.

[4] Saag MS., Holodniy M., Kuritzkes DR.. HIV viral load markers in clinical practice. Nature Medicine 1996; 2: 625.

[5] WHO: HIV/AIDS Programme. Antiretroviral therapy for HIV infection in adults and adolescents: recommendations for public health approach. 2006 revision

[6] Mathews SE., Srivastava D., Bala YR., Sharma A. Association of hematological profile of human immunodeficiency virus-positive patients with clinicoimmunologic stages of the disease. Journal of Laboratory Physicians, 2013; 5: 34-7.
[7] Clinical and Laboratory Monitoring of Antiretroviral Therapy in Resource Limited and Unlimited Settings.WHO HIV/AIDS, Antiretroviral Newsletter. 2000; issue No 4.

[8] Gifford R.J., De-Oliveira T., Rambaut A. UK collaborative Group on HIV Drug Resistance: Phylogenetic surveillance of viral genetic diversity and the evolving molecular epidemiology of human immunodeficiency virus type 1. Journal of Virology. 2007; 81 (23): $13050-56$

[9] Chu H., Gange S J., Yamashita T E., Hoover D R., Joan S. Chmiel J S., Margolick J B., and Jacobson L P. Individual Variation in CD4 Cell Count Trajectory among Human Immunodeficiency Virus-infected Men and Women on Long-term Highly Active Antiretroviral Therapy: An Application using a Bayesian Random Change-Point Model. American Journal of Epidemiology 2005; 162: 787-797.

[10] Decks SG. Barbour JD., Grant RM., Martin JN., Duration and predictors of $\mathrm{CD} 4 \mathrm{~T}$ cell gains in patients who continue combination therapy despite detectable plasma Viraemia. AIDS 2002; 16: 201-207.

[11] Kamga HL., Assob JC., Njunda AL., Nde FP., Nsagha DS., Atanga MB., Weledji P., et al. The kidney function trends in human immunodeficiency virus/acquired immune deficiency syndrome (HIV/AIDS) patients at the Nylon District Hospital, Douala, Cameroon .Journal of AIDS and HIV Research, 2011; 3(2): 30-37.

[12] Christian L., Charles K., Laurence V. Antiretroviral Drug Resistance and Routine Therapy, Cameroon. Emerging Infectious Diseases, 2006; 12(6): 1001-1004

[13] Fokam J., Salpini R., Santoro MM., et al. Drug resistance among drug-naive and first-line antiretroviral treatment-failing children in Cameroon. Pediatric Infectious Disease Journal 2011: 30(12); 1062-8.

[14] Moh R, Danel C, Messou E, Ouassa T, Gabillard D, Anzain A, et al. Determinants of motality and morbidity following early antiretroviral therapy initiation in HIV- infected adults in West Africa. AIDS, 2007; 27: 2483-2491.

[15] Henry DM., Kukwah AT., Mbunkah HA., Bernard AN., Pascal NA et al, Immunohaematologic and virologic responses and predictors of virologic failure in HIV-1 infected adults on firstline antiretroviral therapy in Cameroon. Infectious Diseases of Poverty 2014; 3: 5 .

[16] Christian LC., Gabriele LB., Aghokeng A., Jules B. Monitoring of HIV viral loads, CD4 counts and Clinical assessments versus clinical monitoring alone for antiretroviral therapy in rural district hospitals in Cameroon (Stratall ANRS 12110/ESTHER): a randomized non inferiority trial. 2011.

[17] Moore D R., and Keruly C J. CD4+ Cell Count 6 Years after Commencement of Highly Active Antiretroviral Therapy in Persons with Sustained Virologic Suppression. Clinical Infectious Diseases 2007; 44: 441-6.

[18] Michael CG, Kirk O, Mathiesen L, Nielsen SD. The nai"ve CD4 count in HIV-1-infected patients at time of initiation of highly active anti-retroviral therapy is strongly associated with the level of immunological recovery. Scand J Infect Dis 2002; 34: 45-9.

[19] kaufmann G R., Furrer H., Ledergerber B., Perrin L., Opravil M., Vernazza P., Cavassini M., Bernasconi E., Rickenbach M., Hirschel B., Battegay M. The Swiss HIV cohort study. Characteristics, determinants, and clinical relevance of CD4 T cell recovery to $<500$ cells $/ \mu$ in HIV type 1-infected individuals receiving potent antiretroviral therapy. Clinical Infectious Diseases 2005; 41: 361-372.

[20] Autran B.,Carcelain G., Li TS.,Blanc C., Mathez D., Tubiana R., Katlama C., Debre P., Leibowitch. Positive effects of combined antiretroviral therapy on CD4+ Tcell homeostasis and function in advanced HIV disease. Science 1997; 277: 112-116.

[21] Negredo E., Cruz L., Paredes R., Ruiz L., Fumaz CR., Bonjoch A., Gel S., Tuldra A., Montserrat Balague M., Johnston S., Arno A., Jou A., Tural C., Sirera G., Joan Romeu J., and Clotet B. Virological, Immunological, and Clinical Impact of Switching from Protease Inhibitors to Nevirapine or to Efavirenz in Patients with Human Immunodeficiency Virus Infection and Long-Lasting Viral Suppression. Clinical Infectious Diseases 2002; 34: 504-10.

[22] Evans TG, Bonnez W, Soucier HR, et al. Highly active antiretroviral therapy results in a decrease in $\mathrm{CD} 8+\mathrm{T}$ cell activation and preferential reconstitution of the peripheral CD4+ T cell population with memory rather than naive cells. Anviral Res 1998; 39: 163-73. 
[23] Brookmeyer R, Gail MH 1994. AIDS Epidemiology: A Quantitative Approach. New York, Oxford, $354 \mathrm{pp}$.

[24] Hess C, Altfeld M, Thomas SY, Addo MM, Rosenberg ES, et al. (2004) HIV-1 specific CD8+T cells with an effector phenotype and control of viral replication. Lancet 363: 863-866.

[25] van Baarle D, Kostense S, van Oers MH, Hamann D, Miedema F. Failing immune control as a result of impaired CD8+ T-cell maturation: CD27 might provide a clue. Trends Immunol 23 (12): 586-591, 2002

[26] Mocroft A, Kirk O, Barton SE, EuroSIDA Study Group (1999) Anemia is an independent predictive marker for clinical prognosis in HIV infected patients across Europe. AIDS 13: 943-950.

[27] Huang SS, Barbour JD, Deeks SG, Huang SJ, Grant RM et al (2000) Reversal of human immunodeficiency Virus type 1Associated hematosuppression by effective antiretroviral therapy. Clin Infect Dis 30: 504-510.

[28] Ellaurie M, Bernstein LJ, Shah K et al (1986) Thrombocytopenia in Paediatrics AIDS. Blood 68:124a.

[29] Landrø L, Ueland T, Otterdal K, Frøland SS, Aukrust P. Persistently raised plasma levels of platelet-derived inflammatory mediators in HIV-infected patients during highly active antiretroviral therapy. J Thromb Haemost. 2011 May; 9 (5): 1075-7.

[30] Gleissner CA, von Hundelshausen, Ley K. Platelet chemokines in vascular disease. Arterioscler Thromb Vasc Biol 2008; 28: 1920-7.
[31] Weyrich AS, Zimmerman GA. Platelets: signaling cells in the immune continuum. Trends Immunol 2004; 25: 489-95.

[32] Berger EA, Murphy PM, Farber JM. Chemokine receptors as HIV-1 coreceptors: roles in viral entry, tropism, and disease. Annu Rev Immunol 1999; 17: 657-700.

[33] Claudio M., Miriam L., Fabio M., Claudia D., Gabriele F., Gabriella D, Paola S and Vincenzo V. Improvement in neutrophil and monocyte function during highly active antiretroviral treatment of HIV-1-infected patients. AIDS 1999, 13: 883-890.

[34] Elizabeth GK., Ruth N, Dalton W and Nyambura K. Impact of highly active antiretroviral therapy on hematological indices among HIV- 1 infected children at Kenyatta National HospitalKenya: retrospective study. AIDS Res Ther (2015) 12: 26.

[35] Al Mohajer M, Villarreal-Williams E, Andrade RA, Giordano TP, Serpa JA. Eosinophilia and associated factors in a large cohort of patients infected with human immunodeficiency virus. South Med J. 2014 Sep; 107(9): 554-8.

[36] Sivaram M, White A, Radcliffe KW. Eosinophilia: clinical significance in HIV-infected individuals. Int J STD AIDS. 2012 Sep; 23(9): 635-8

[37] Tietz A, Sponagel L, Erb P, Bucher H, Battegay M, Zimmerli W. Eosinophilia in patients infected with the human immunodeficiency virus. Eur J Clin Microbiol Infect Dis. 1997 Sep; 16(9): 675-7. 